\title{
CHARACTERIZATION AND LOCALIZATION OF ADENOSINE RECEPTORS IN RAT SPINAL CORD ${ }^{1}$
}

\author{
J. D. GEIGER, ${ }^{* 2}$ F. S. LABELLA,* AND J. I. NAGY \\ Departments of *Pharmacology and Therapeutics and $\ddagger$ Physiology, University of Manitoba, Faculty of Medicine, Winnipeg, \\ Manitoba R3E OW3 Canada
}

Received February 11, 1984; Revised March 8, 1984; Accepted March 12, 1984

\begin{abstract}
Adenosine $\mathrm{A}_{1}$ receptors were characterized in membranes from rat dorsal and ventral spinal cord using $\left[{ }^{3} \mathrm{H}\right]$ cyclohexyladenosine $\left(\left[{ }^{3} \mathrm{H}\right] \mathrm{CHA}\right)$ and compared with those in brain. For determination of anatomical loci of adenosine $A_{1}$ receptors in the dorsal and ventral spinal cord, various lesions were employed, including kainic acid injections directly into the lumbar dorsal spinal cord, spinal cord hemitransections, dorsal rhizotomies, and neonatal capsaicin treatment. In control animals a single high affinity binding component was observed in dorsal and ventral spinal cord with $K_{D}$ values of 2.3 and $2.6 \mathrm{nM}$ and $B_{\max }$ values of 170 and $123 \mathrm{fmol} / \mathrm{mg}$ of protein, respectively. In comparison, $\left[{ }^{3} \mathrm{H}\right] \mathrm{CHA}$ binding to whole brain membranes exhibited $K_{D}$ and $B_{\max }$ values of $2.3 \mathrm{nM}$ and $301 \mathrm{fmol} / \mathrm{mg}$ of protein, respectively. The $\mathrm{IC}_{50}$ values for CHA, (-)-phenylisopropyl adenosine, adenosine-5' -ethylcarboxamide, 2-chloroadenosine, (+)-phenylisopropyl adenosine, and theophylline to displace $\left[{ }^{3} \mathrm{H}\right] \mathrm{CHA}$ were $3.6,2.3,15,17,21$, and $30,500 \mathrm{nM}$ for dorsal horn and 5.1, 2.7, 9.8, 24, 25, and 21,000 $\mathrm{nM}$ for ventral horn. The potencies of the various ligands are similar to those found for brain tissue. Injection of kainic acid direstly into the dorsal spinal cord significantly reduced specific $\left[{ }^{3} \mathrm{H}\right] \mathrm{CHA}$ binding by $33 \%$ in this tissue when compared to values from saline-injected control animals. This decrease was accompanied histologically by the depletion of intrinsic neuronal cell bodies and extensive gliosis at the injection site. Terminals of descending or primary afferent systems appear not to contain $\left[{ }^{3} \mathrm{H}\right] \mathrm{CHA}$-binding sites since lesions which interrupt these systems failed to alter the levels of $\left[{ }^{3} \mathrm{H}\right] \mathrm{CHA}$ receptors in denervated spinal cord tissue. The results indicate that adenosine $A_{1}$ receptors in dorsal and ventral horn are similar qualitatively and quantitatively to those found in brain. Furthermore, it appears that adenosine receptors labeled by $\left[{ }^{3} \mathrm{H}\right] \mathrm{CHA}$ in the dorsal horn are located on neurons intrinsic to this structure.
\end{abstract}

The proposition that adenosine functions as a regulator of neuronal activity in the CNS has been underscored by observations that stable adenosine analogues produce marked behavioral changes in animals (Phillis and Wu, 1981) and alter the release of transmitter substances in both the peripheral and central nervous systems (Fredholm and Hedqvist, 1980). One approach to assess the putative transmitter role for adenosine is the identification of the CNS regions and, more specifically, the neural systems upon which specific high affinity adenosine receptors are located (Daly et al., 1981). The notion that receptor location delineates sites of action of adenosine is supported in the rat hippocampus, where a correlation was found between the densities of adenosine receptors and the ability of adenosine to alter evoked potentials (Lee et al., 1983). Other systems rich in adenosine receptors include striatal (Wojcik and Neff, 1983a) and hippocampal (Murray and Cheney, 1982) interneurons, parallel fibers and terminals of cere-

\footnotetext{
${ }^{1}$ This work was supported by grants from the Manitoba Mental Health Research Foundation and the University of Manitoba Faculty Fund to J. I. N., who is a Scholar of the Medical Research Council of Canada, and from the Medical Research Council of Canada to F. S. L., who is a Career Investigator of the Medical Research Council of Canada. J. D. G. is a Fellow of the Manitoba Health Research Council.

${ }^{2}$ To whom correspondence should be addressed.
}

bellar granule cells, and retinal projections to the superior colliculus (Goodman et al., 1983; Wojcik and Neff, 1983b). Thus, receptors in these CNS regions may be functionally involved in the actions of adenosine and its analogues (Daly et al., 1981; Goodman and Snyder, 1982).

Although adenosine receptors have been examined extensively in brain, very little is known concerning these in spinal cord. We have previously found that $\left[{ }^{3} \mathrm{H}\right]-N^{6}$-cyclohexyladenosine ( $\left.\left[{ }^{3} \mathrm{I}\right] \mathrm{CHA}\right)$-binding sites in membranes from whole spinal cord exhibit levels and affinities comparable to those in brain (Geiger et al., 1984). However, in brain two receptor subtypes have been identified based, in part, on the ability of adenosine and adenosine analogues to inhibit $\left(A_{1}\right)$ or stimulate $\left(A_{2}\right)$ adenylate cyclase activity (Van Calker et al., 1979; Londos et al., 1980). Radioligands bound to high affinity (nanomolar $K_{D}$ ) $\mathrm{A}_{1}$ sites are preferentially and stereospecifically displaced by $(-)$ phenylisopropyl adenosine (PIA), while the lower affinity (micromolar $K_{D}$ ) $\mathrm{A}_{2}$ sites are affected equipotently by (-)- and (+) PIA. A comparable classification of adenosine receptors in spinal cord has not been reported. Our interest in these receptors in spinal cord stems from several observations. First, Goodman and Snyder (1982), using radioautography, described the substantia gelatinosa (SG) of the spinal cord as a CNS area containing high levels of adenosine receptors. The $S G$ is a major termination area for primary sensory afferents and some 
descending spinal systems, thus intimating a role for adenosine in sensory function. Second, there is renewed interest in the proposal (Holton and Holton, 1954; Holton 1959) that ATP may function as a primary afferent transmitter. Electrophysiological studies have shown that neurons in the cuneate nucleus (Galindo et al., 1967), sensory ganglia in the cat and rat (Krishtal et al., 1983), the caudal trigeminal nucleus in the rat (Salt and Hill, 1983), and the dorsal horn (Jahr and Jessell, 1983) respond to adenine nucleosides and/or nucleotides. These findings, together with the observation that the $\mathrm{SG}$ is rich in 5 '-nucleotidase (Scott, 1967), an enzyme responsible for degradation of AMP to adenosine, suggest a relationship between the actions of ATP and its degradation product, adenosine (Schubert et al., 1974). Finally, while adenosine agonists reportedly have sedative properties and decrease locomotor activity in animals, it is also clear that these agonists increase (Crawley et al., 1981; Yarbrough and McGuffin-Clineschmidt, 1981; Holmgren et al., 1983) and adenosine antagonists (i.e., methylxanthines) decrease nociceptive thresholds in rats (Paalzow and Paalzow, 1973), possibly through a direct action on adenosine receptors at the spinal level. The present investigations were designed to characterize adenosine receptors in rat spinal cord and to determine the spinal neural systems with which they are associated.

\section{Materials and Methods}

Animal preparation. Male Sprague-Dawley rats weighing between 250 and $350 \mathrm{gm}$ were used in these studies. Two procedures were employed to evaluate the occurrence of adenosine receptors on axon terminals of primary afferents in the spinal cord. In the first, animals were treated neonatally to deplete them of unmyelinated primary afferent fibers. Two-day-old rat pups were injected subcutaneously with either $50 \mathrm{mg} / \mathrm{kg}$ of capsaicin dissolved in a $0.9 \%$ saline vehicle containing $10 \%$ Tween- 80 and $10 \%$ ethanol, or vehicle alone (controls). The capsaicin and control animals were sacrificed 45 to 60 days later This treatment depletes up to $90 \%$ of the unmyelinated $\mathrm{C}$ fibers in the dorsal roots of adult animals (Nagy et al., 1983). In the present study the effectiveness of the treatment was verified, in part, by observations of a prolongation of response latencies in nociceptive tests using the hot plate method (Nagy and Van der Kooy, 1983). In addition, histological examination of dorsal root ganglia from capsaicin-treated animals showed large reductions in the number of small fluoride-resistant acid phosphatase- and substance P-containing type $B$ neurons (data not shown) consistent with previous observations (Nagy and Hunt, 1982; Nagy et al., 1983). The second procedure involved severing the primary afferent input to the spinal cord. All surgical procedures were performed aseptically on adult animals while anesthetized with Equithesin (Scadding, 1981). Dorsal rhizotomies were performed on four adult rats, while another four underwent sham operations. A small portion of the vertebral column was exposed caudal to the lumbar enlargement. Following laminectomy between the first and second lumbar ganglia, being careful not to damage the dura, the dorsal roots on the left side were transected, resulting in unilateral denervation of the major part of the lumbar enlargement. This spinal area was subsequently packed with sterile Gelfoam, the muscle and skin layers were sutured, and animals were allowed to recover for 9 days. To assess the presence of $\left[{ }^{3} \mathrm{H}\right] \mathrm{CHA}$-binding sites on descending neuronal systems, hemitransections were conducted on four animals. A similar surgical approach was used as for dorsal rhizotomies, except that a narrow portion of the cord, yet sufficient to visualize the midline, was exposed at the low thoracic level just rostral to the lumbar enlargement. A single knife cut was then placed through the left side of the cord transecting both the dorsal and ventral horns and associated white matter. Sham-operated animals served as controls, and all animals were sacrificed 9 days later. Animals recovered quickly from these surgical procedures and were free of infection.

To evaluate a neural location of adenosine receptors in spinal cord, kainic acid (KA, $2.0 \mathrm{nmol}, 0.2 \mu \mathrm{l}$ in phosphate-buffered $0.9 \%$ saline, $\mathrm{pH}$ 7.4), a neurotoxic agent which lesions intrinsic cell bodies without affecting fibers of passage, was injected into the dorsal horn at the lumbar enlargement. A Hamilton syringe fitted with a 32 gauge needle with the bevel removed (to limit the spread of kainic acid at the injection site) was used for these injections. To avoid mechanical damage to the dorsal horn, the needle was inserted just medial to Lissauer's tract, through the dorsal column, to a middorsal-ventral position in the dorsal cord. The injection was given at two sites separated by approximately $1.0 \mathrm{~cm}$ on opposite sides of the cord over a 15 -min period. Control animals included unoperated rats as well as those similarly operated on but receiving PBS injections into the dorsal horn. To eliminate subjecting animals to the well documented acute excitatory actions of KA following injections of this compound into the CNS, animals were maintained under Equithesin anesthesia for a period of $2 \mathrm{hr}$. Small injection volumes were used to limit the spread of KA to the ventral horn, which caused its destruction. Recovery from this treatment was uneventful, and animals exhibited minimal locomotive impairment. After a survival time of 7 days, some animals were taken for histological verification of neuronal loss in the dorsal horn. These animals were deeply anesthetized with chloral hydrate and perfused transcardially with $0.9 \%$ saline followed by $300 \mathrm{ml}$ of phosphate-buffered (0.1 $\mathrm{m}$ sodium phosphate, $\mathrm{pH} 7.4$ ) $10 \%$ formalin. The spinal cord was excised, postfixed in this same fixative for $4 \mathrm{hr}$, and transferred to $30 \%$ sucrose overnight. Parasagittal sections were obtained on a freezing microtome and stained with cresyl violet.

Tissue dissection. Following the respective recovery periods, animals were decapitated, spinal cords were excised, and pia mater was removed. The cord was placed on wetted paper towels resting on ice-cold metal plates, sliced transversely into approximately $1-\mathrm{mm}$ thick sections, and dorsal and ventral cords were isolated. Receptor-binding assays conducted on tissue obtained from KA-injected animals included only 0.5 $\mathrm{cm}$ of spinal cord on either side of the injection sites, corresponding to approximately 50 (dorsal) and 140 (ventral) mg of tissue/animal. Tissues from animals receiving dorsal rhizotomies included only the lumbar enlargement of the spinal cord, which was dissected into left and right in addition to dorsal and ventral regions. Dorsal and ventral cord regions were taken from both cervical and lumbar areas of capsaicintreated animals, and these tissues were analyzed separately. Dorsal and ventral roots were also obtained from control and capsaicin-treated animals. Tissues from sham-operated or control animals were similarly obtained.

For the characterization of adenosine receptors in normal tissues, the dorsal cervical and lumbar regions of the spinal cord were dissected, pooled, and analyzed separately from the corresponding ventral regions. In one set of experiments involving normal tissue, the dorsal and ventral horns (grey matter) were dissected free of surrounding white matter with the aid of a dissecting microscope. After dissection, all tissues were frozen on dry ice, weighed, and stored at $-70^{\circ} \mathrm{C}$ until assayed. To compare $\left[{ }^{3} \mathrm{H}\right] \mathrm{CHA}$-binding data between spinal cord and brain, whole brains were excised, frozen on dry ice, and processed for receptor binding as described for spinal cord tissue.

Receptor assay. The tissues were prepared for receptor-binding stud ies essentially as described by Geiger et al. (1984). Briefly, the tissue was placed in centrifuge tubes containing $10 \mathrm{vol}$ of ice-cold $50 \mathrm{~mm}$ Tris-HCl buffer at $\mathrm{pH} 7.4$ (Tris buffer) and homogenized with a Polytron set at medium speed for 20 sec. The homogenate was centrifuged at $35,000 \times g$ for $15 \mathrm{~min}$, and the membrane pellet was resuspended and centrifuged as above. The pellet was resuspended in Tris buffer containing $1 \mathrm{IU} / \mathrm{ml}$ of adenosine deaminase, incubated for 30 min at $37^{\circ} \mathrm{C}$, and centrifuged as above. The pellets were resuspended by Polytron homogenization in Tris buffer, and this suspension (2 to 5 $\mathrm{mg}$ of protein $/ \mathrm{ml}$ ) was used for receptor-binding assays. Protein was determined in aliquots of this final suspension by the method of Lowry et al. (1951) using BSA as standard.

Receptor-binding saturation studies were conducted in a total volume of $1 \mathrm{ml}$ of Tris buffer containing 0.08 to $60 \mathrm{nM}\left[{ }^{3} \mathrm{H}\right] \mathrm{CHA}, 200$ to $500 \mu \mathrm{g}$ of membrane protein, and in the absence or presence of $10 \mu \mathrm{M}$ (-)-PIA. Specific displaceable binding was calculated as total binding (absence of (-)-PIA) minus binding of the presence of (-)-PIA (nonspecific binding). Due to limited spinal cord tissue available from animals subjected to KA, hemitransection, or rhizotomy, specific $\left[{ }^{3} \mathrm{H}\right]$ $\mathrm{CHA}$ binding was assessed using a single concentration of $\left[{ }^{3} \mathrm{H}\right] \mathrm{CHA}(2$ to $2.5 \mathrm{nM}$ ) and either $10 \mu \mathrm{M}$ CHA or (-)-PIA for determination of nonspecific binding. Nonspecific binding in dorsal and ventral spinal cord and in whole brain was consistently less than $10 \%$ of total binding. In typical experiments using $2.2 \mathrm{nM}\left[{ }^{3} \mathrm{H}\right] \mathrm{CHA}$, total and nonspecific binding values (counts per minute per milligram of protein) for brain were 2495 and 149,1600 and 143 for dorsal spinal cord, and 910 and 73 for ventral spinal cord, respectively. $\mathrm{IC}_{60}$ values for $\mathrm{CHA},(-)$-PIA, 
(+)-PIA, adenosine-5' -ethylcarboxamide (NECA), and 2-chloroadenosine (2Cl-Ad) were determined using 8 to 10 concentrations of these displacers ranging from 0.15 to $10,000 \mathrm{nM}$, while displacing concentrations of theophylline ranged from 0.15 to $1000 \mu \mathrm{M}$. Incubations were for $2 \mathrm{hr}$ at $25^{\circ} \mathrm{C}$ and were terminated by rapid filtration through Whatman GF/B filters under reduced pressure. Ice-cold Tris buffer (3 ml) was added to each tube and poured onto the filters, which were additionally washed with $10 \mathrm{ml}$ of Tris buffer. The filters were placed into scintillation vials, $10 \mathrm{ml}$ of ACS scintillation fluid (Amersham) were added, and, following a 12 -hr interval, they were counted in a Beckman LS8100 scintillation counter at $38 \%$ efficiency. The saturation data were analyzed by the nonlinear multipurpose curve-fitting program LIGAND (Munson and Rodbard, 1980) to generate values for dissociation constants $\left(K_{D}\right)$ and number of receptors sites $\left(B_{\max }\right)$. All other data were analyzed according to variance, and Dunnett's multiple comparison and the Student's $t$ tests were used for determination of statistical significance. Values cited in the text represent the mean \pm SEM.

Autoradiographic studies. For autoradiographic localization of $\left[{ }^{3} \mathrm{H}\right]$ CHA-binding sites in spinal cord, animals were decapitated, and the lumbar enlargement of the cords was excised, mounted on microtome chucks, and rapidly frozen. Cryostat sections $(10 \mu \mathrm{m})$, cut in the parasaggital and transverse planes, were mounted onto cold gelatinized slides and washed in $50 \mathrm{mM}$ Tris-HCl buffer (pH 7.4) for $30 \mathrm{~min}$ at $20^{\circ} \mathrm{C}$. The sections were then incubated in fresh Tris buffer containing $5.0 \mathrm{nM}\left[{ }^{3} \mathrm{H}\right] \mathrm{CHA}$ for $90 \mathrm{~min}$ at $20^{\circ} \mathrm{C}$, washed twice in Tris buffer for $10 \mathrm{~min}$, and allowed to air dry overnight at $4^{\circ} \mathrm{C}$. Adjacent sections, similarly processed but incubated in the presence of $10 \mu \mathrm{M}$ unlabeled (-)-PIA, served as a measure of nonspecific binding. The dry sections were placed firmly in contact with LKB Ultrofilm, exposed for 3 weeks at $4^{\circ} \mathrm{C}$, and developed using Kodak D76 developer. To localize silver grains, autoradiograms and corresponding tissue sections were examined under darkfield illumination using a Wild-Leitz microscope.
Materials. Chemicals were obtained as follows. Theophylline, 2chloroadenosine, capsaicin, KA, and adenosine deaminase type VII were from Sigma Chemical Co. (St. Louis, MO). $(-)-N^{6}$-Phenylisopropyl adenosine and $N^{6}$-cyclohexyladenosine were purchased from Boehringer Mannheim (Dorval, Quebec, Canada). (+)- $N^{6}$-Phenylisopropyl adenosine was obtained from Research Biochemicals (Wayland, MA). $\left[{ }^{3} \mathrm{H}\right]-N^{6}$-Cyclohexyladenosine was purchased from New England $\mathrm{Nu}-$ clear (Boston, MA). Adenosine-5'-ethylcarboxamide was kindly supplied by Dr. E. L. Waroch (Abbott Laboratories, Chicago, IL).

\section{Results}

Adenosine receptors in normal tissue. The results of the characterization of $\left[{ }^{3} \mathrm{H}\right] \mathrm{CHA}$-binding sites in dorsal and ventral spinal cord using saturation studies and nonlinear iterative analysis of the data are shown in Figure 1. The isotherms indicate that these receptor sites were saturated by the concentrations of $\left[{ }^{3} \mathrm{H}\right] \mathrm{CHA}$ and incubation conditions employed. Scatchard plots derived from these saturation isotherms (Fig. 1, inset) yielded $K_{D}$ values for dorsal and ventral tissue of 2.3 and $2.6 \mathrm{nM}$ and $B_{\max }$ values of 176 and $122 \mathrm{fmol} / \mathrm{mg}$ of protein, respectively. In comparison, the $K_{D}$ and $B_{\max }$ values for whole brain were $2.3 \mathrm{nM}$ and $301 \mathrm{fmol} / \mathrm{mg}$ of protein, respectively (saturation plot not shown). In dorsal and ventral spinal tissue and in brain, only one binding component was observed. This was confirmed using the computer program LIGAND and linear regression analysis, where greater than 0.95 correlation coefficients were obtained for the least squares best fit line drawn through the data points on Scatchard plots. When white matter was carefully dissected away from dorsal and ventral grey matter, $\left[{ }^{3} \mathrm{H}\right] \mathrm{CHA}$ binding was enhanced by $93 \%$ and $27 \%$,

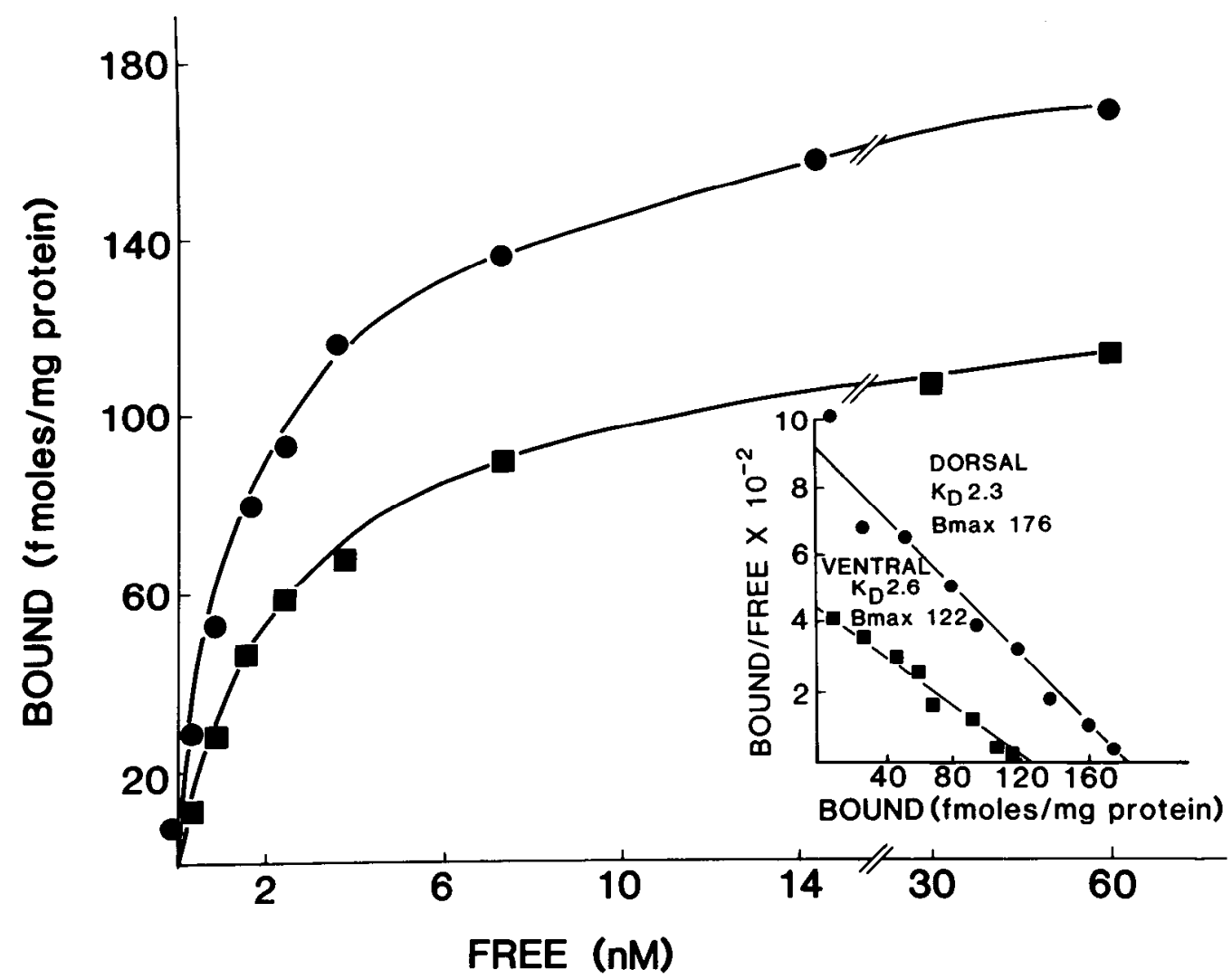

Figure 1. Saturation analysis of $\left[{ }^{3} \mathrm{H}\right] \mathrm{CHA}$ binding to membranes prepared from rat dorsal and ventral spinal cord. Specific $\left[{ }^{3} \mathrm{H}\right] \mathrm{CHA}$ binding to membranes of dorsal $(\circlearrowleft)$ and ventral $(\square)$ spinal cord is illustrated as saturation isotherms and Scatchard plots. Specific binding was calculated as the difference between total and nonspecific binding (in the presence of $10 \mu \mathrm{M}(-)$-PIA) from samples assayed in duplicate. The $K_{D}$ and $B_{\max }$ values were derived from computer analysis of the data according to the program LIGAND (Munson and Rodbard, 1980). Membranes from whole rat brain were assayed in a similar manner. Experiments were conducted at least twice with similar results. 
respectively, compared to the typical dorsal and ventral cord values shown in Table II. This finding was further confirmed in our autoradiographs of the spinal cord (see Fig. 3) where receptors were highly localized to the grey matter in both dorsal and ventral spinal cord.

The results of displacement studies of $\left[{ }^{3} \mathrm{H}\right] \mathrm{CHA}$ binding from sites in rat spinal cord and whole brain using various adenosine receptor agonists and the antagonist theophylline are shown in Figure 2, $A$ to $C$, where the curves have been plotted on the
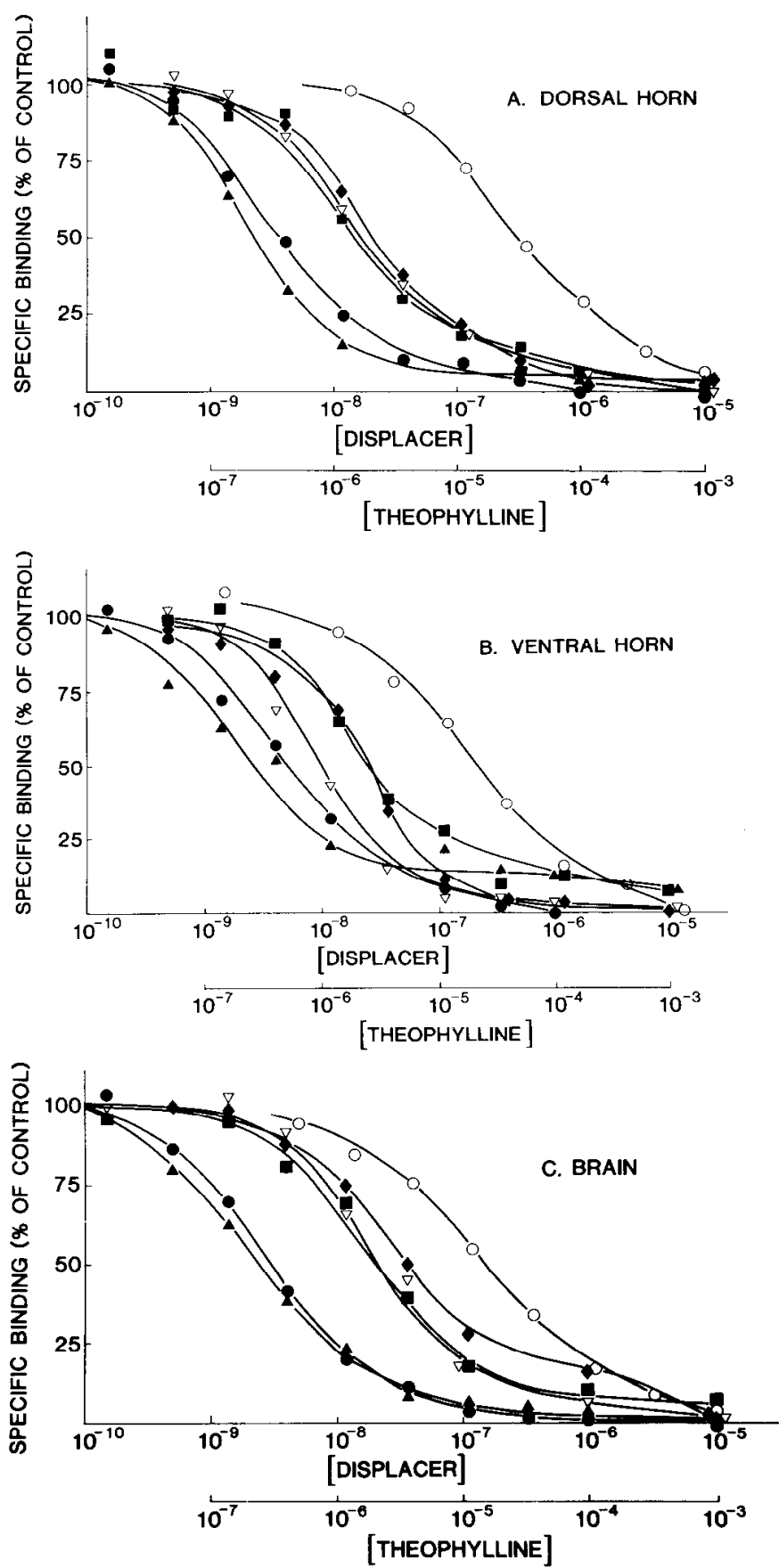

Figure 2. Displacement of $\left[{ }^{3} \mathrm{H}\right] \mathrm{CHA}$ binding to membranes of rat dorsal $(A)$ and ventral $(B)$ spinal cord and brain $(C)$ by various adenosine analogues. $\mathrm{IC}_{50}$ values for $\mathrm{CHA}(\boldsymbol{\bullet}),(-)$-PIA $(\boldsymbol{A})$, NECA $(\boldsymbol{\square}), 2 \mathrm{Cl}$-Ad $(\nabla),(+)$-PIA $(\$)$, and theophylline $(O)$ were determined using 2.0 to $2.5 \mathrm{nM}\left[{ }^{3} \mathrm{H}\right] \mathrm{CHA}, 8$ to 10 concentrations of the displacers, and $10 \mu \mathrm{M}$ CHA to define nonspecific binding. The results illustrated are representative of studies conducted in duplicate and performed at least twice with similar results.
TABLE I

$I C_{50}$ values of various compounds for the displacement of $\left[{ }^{3} \mathrm{H}\right] \mathrm{CHA}$ binding to rat brain and spinal cord

Values represent means of experiments performed in duplicate (graphically illustrated in Fig. 2) and repeated twice with similar results. The $K_{i}$ values (in parentheses) were calculated using the Cheng-Prusoff (1973) equation; $K_{i}=I C_{50} /\left(1+L / K_{D}\right) . L$ represents the concentration of label used (2.3 nM $\left[{ }^{3} \mathrm{H}\right] \mathrm{CHA}$ ), and $K_{D}$ is the equilibrium dissociation constant for $\left[{ }^{3} \mathrm{H}\right] \mathrm{CHA}$ binding to brain $(2.3 \mathrm{nM})$, dorsal spinal cord (2.3 nM), and ventral spinal cord (2.6 nM).

\begin{tabular}{lccc}
\hline \multirow{2}{*}{ Displacer } & \multicolumn{3}{c}{$\mathrm{IC}_{50}$ and $K_{i}$ values } \\
\cline { 2 - 4 } & Whole Brain & \multicolumn{2}{c}{ Spinal Cord } \\
& & Dorsal & Ventral \\
\hline CHA & $3.0(1.5)$ & $3.6(1.8)$ & $5.1(2.7)$ \\
(-)-PIA & $2.4(1.2)$ & $2.3(1.2)$ & $2.7(1.4)$ \\
NECA & $20(10)$ & $15(7.5)$ & $9.8(5.2)$ \\
2Cl-Ad & $21(10.5)$ & $17(8.5)$ & $24(12.7)$ \\
(+)-PIA & $37(18.5)$ & $21(10.5)$ & $25(13.3)$ \\
Theophylline & $15,500(7,750)$ & $30,500(15,250)$ & $21,000(11,141)$ \\
\hline
\end{tabular}

basis of percentage of control binding. The $\mathrm{IC}_{50}$ and $K_{i}$ values for the various displacers are listed in Table I. With few exceptions, the adenosine receptors in dorsal and ventral spinal cord and whole brain had similar specificities. The $\mathrm{IC}_{50}$ values for theophylline and NECA exhibited the greatest variation among the three tissues studied with the highest affinity for theophylline observed in whole brain and for NECA in ventral spinal cord. The $\mathrm{IC}_{b 0}$ values for NECA and $2 \mathrm{Cl}$ Ad were similar in brain and dorsal spinal cord; however, NECA showed a 2.4fold higher affinity than $2 \mathrm{Cl}$-Ad for the $\left[{ }^{3} \mathrm{H}\right] \mathrm{CHA}$ site in ventral spinal cord. The affinity of (-)-PIA was 15 times greater than (+)-PIA for $\left[{ }^{3} \mathrm{H}\right] \mathrm{CHA}$ sites in whole brain membranes and 9 times higher for these sites in both dorsal and ventral horn tissue. These displacement affinities were confirmed in at least two separate experiments.

Autoradiographic studies. The results of the autoradiographic studies of $\left[{ }^{3} \mathrm{H}\right] \mathrm{CHA}$ binding in spinal cord are shown in Figure 3. In both parasagittal and transverse sections, the density of silver grains was clearly highest in the SG. The resolution of the autoradiographs using Ultrofilm did not allow definitive determination of whether $\left[{ }^{3} \mathrm{H}\right] \mathrm{CHA}$ labeling of adenosine receptors was uniformly high throughout the SG. The grain density in the rest of the dorsal horn and in the ventral horn was distinguishably greater than the control background. For white matter and control sections incubated in the presence of both $\left[{ }^{3} \mathrm{H}\right] \mathrm{CHA}$ and unlabeled (-)-PIA, the grain density was virtually equal to that present in film which was not in contact with either tissue or the microscope slide. This is consistent with the low nonspecific binding observed in the present experiments involving tissue homogenates and also indicates the absence of chemographic effects.

Lesion studies. The effects of denervating the lumbar spinal cord of various fiber inputs on $\left[{ }^{3} \mathrm{H}\right] \mathrm{CHA}$-binding sites in this region are shown in Table II. It is evident that severing descending neural systems through spinal hemitransections, depleting unmyelinated primary afferents through neonatal capsaicin treatment, or unilaterally denervating the lumbar enlargement of both unmyelinated and myelinated fiber input all failed to alter the levels of $\left[{ }^{3} \mathrm{H}\right] \mathrm{CHA}$ receptors in the denervated tissues. Saturation analysis of adenosine receptors in dorsal spinal cord of capsaicin and control animals showed no differences in $K_{D}$ values $(6.1$ and $5.7 \mathrm{nM})$ or $B_{\max }$ values $(525.6 \pm 29.3$ and 488.2 $\pm 9.7 \mathrm{fmol} / \mathrm{mg}$ of protein), respectively. The estimates of $\left[{ }^{3} \mathrm{H}\right]$ CHA binding to dorsal roots from five control and five capsaicin-treated animals were $5.2 \pm 1.4$ and $5.2 \pm 1.2 \mathrm{fmol} / \mathrm{mg}$ of 

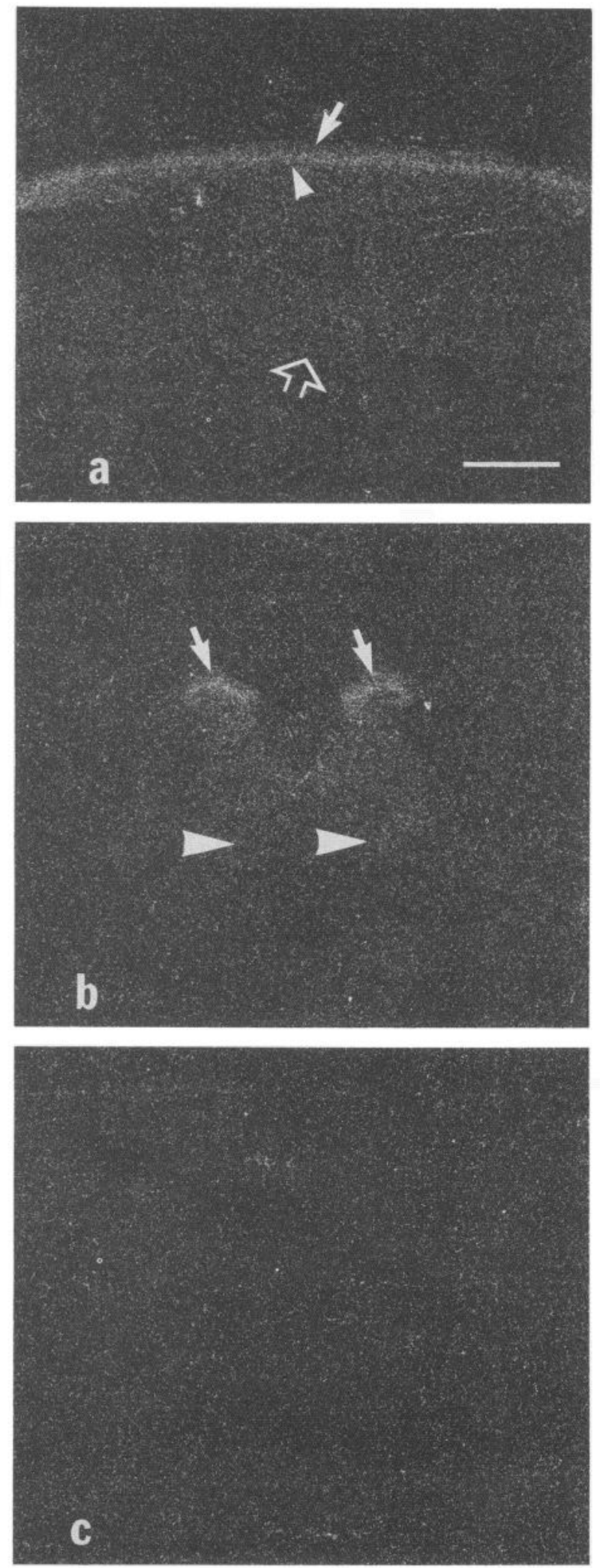

Figure 3. Autoradiographic demonstration of $\left[{ }^{3} \mathrm{H}\right] \mathrm{CHA}$ binding to adenosine receptors in sections of spinal cord. Tissues were sectioned on a cryostat, incubated in $5.0 \mathrm{nM}\left[{ }^{3} \mathrm{H}\right] \mathrm{CHA}$, and exposed to tritiumsensitive LKB Ultrofilm. The autoradiograms were printed directly on photographic paper. $a$, Parasagittal section of lumbar spinal cord at the level of the dorsal root entry zone. Just beneath the dorsal surface of the cord (arrow) and within the SG is a dense band of autoradiographic grains along the entire length of the section. The arrowhead indicates
TABLE II

Effects of unilateral rhizotomies, spinal hemitransections, and neonatal capsaicin treatment on adenosine receptors in adult spinal cords

Adult male Sprague-Dawley rats were subjected to left dorsal rhizotomies and sacrificed 9 days later, or left-sided hemitransections and sacrificed 10 days later, or were sham-operated. Sprague-Dawley rat pups were injected with capsaicin $(50 \mathrm{mg} / \mathrm{kg})$ on the second postnatal day and sacrificed 45 to 60 days later. Spinal cord segments were dissected, and specific binding was determined as total binding ( 2 to $\left.2.5 \mathrm{nM}\left[{ }^{3} \mathrm{H}\right] \mathrm{CHA}\right)$ minus nonspecific binding in the presence of $10 \mu \mathrm{M}$ CHA. All samples were assayed in triplicate, and values represent means \pm SEM from at least four animals in each group. No significant differences were noted between control and lesioned tissues.

\begin{tabular}{|c|c|c|c|c|c|}
\hline \multirow{3}{*}{$\begin{array}{l}\text { Spinal } \\
\text { Region }\end{array}$} & \multicolumn{5}{|c|}{ Treatment } \\
\hline & \multicolumn{2}{|c|}{ Hemitransections } & \multicolumn{2}{|c|}{ Dorsal Rhizotomy } & \multirow{2}{*}{$\begin{array}{c}\text { Neontal } \\
\text { Capsaicin }\end{array}$} \\
\hline & Left & Right & Left & Right & \\
\hline & \multicolumn{5}{|c|}{ specific binding ( $f \mathrm{~mol} / \mathrm{mg}$ of protein) } \\
\hline \multicolumn{6}{|l|}{ Dorsal } \\
\hline Control & $138 \pm 11$ & $146 \pm 8$ & $152 \pm 12$ & $163 \pm 16$ & $155 \pm 2$ \\
\hline Lesion & $120 \pm 11$ & $134 \pm 18$ & $142 \pm 4$ & $156 \pm 16$ & $152 \pm 5$ \\
\hline \multicolumn{6}{|l|}{ Ventral } \\
\hline Control & $80 \pm 6$ & $72 \pm 5$ & $88 \pm 7$ & $92 \pm 6$ & $80 \pm 1$ \\
\hline Lesion & $78 \pm 7$ & $76 \pm 6$ & $88 \pm 7$ & $92 \pm 7$ & $77 \pm 4$ \\
\hline
\end{tabular}

protein and to ventral roots were $8.4 \pm 2.0$ and $7.5 \pm 1.3 \mathrm{fmol} /$ $\mathrm{mg}$ of protein, respectively. Although these levels are low, similar values were obtained on three separate occasions. $\left[{ }^{3} \mathrm{H}\right]$ $\mathrm{CHA}$ binding to membranes prepared from dorsal root ganglia was too variable to provide reliable measurements.

Spinal cords from three of the KA-injected animals showed neuron loss and extensive gliosis, histologically, which was consistent in all animals and extended for a rostrocaudal distance of between 0.6 and $0.9 \mathrm{~cm}$. The lesion did not extend to the ventral horn, thereby sparing its constituent motor neurons and interneurons. Neuronal loss and gliosis were most pronounced in layers I through IV, as shown in a representative sample in Figure 4. However, neurons of layers III and IV appeared most susceptible to $\mathrm{KA}$ and degenerated over a slightly greater rostrocaudal distance $(0.9 \mathrm{~cm})$ than the smaller, more superficial neurons in the SG (layer II) $(0.6 \mathrm{~cm})$. Moreover, in contrast to deeper neurons, there was some sparing of small neurons at the extreme lateral portion of the SG as far as $0.4 \mathrm{~cm}$ from the injection site. Since the $\mathrm{SG}$ is densely packed with cells, these differences in susceptibility to KA neurotoxicity may be due to diffusional barriers. Alternatively, neurons in SG may be inherently more resistant to KA than those in deeper layers. In any event, it was evident that substantial neuronal degeneration occurred in both SG and deeper dorsal horn layers. As shown in Table III, this neuron loss was accompanied by a significant depletion $(33 \%)$ of $\left[{ }^{3} \mathrm{H}\right] \mathrm{CHA}$ binding sites in dorsal but not ventral horns of $\mathrm{KA}$ versus saline-injected animals. Saturation analysis of these tissues was precluded by the small amounts of available tissue. Wet tissue weights from KA, saline, and sham-injected animals were respectively, $25.8 \pm 1.2,24.6 \pm 2.8$, and $28.6 \pm 2.4 \mathrm{mg}$ for dorsal horn and $61.0 \pm 3.0,62.0 \pm 2.9$, and $77.4 \pm 2.6 \mathrm{mg}$ for ventral spinal cord.

the ventral border of the SG, and the open arrow indicates the ventral edge of the spinal cord section. $b$, Transverse section of lumbar spinal cord showing accumulation of grains in the SG (arrows). Arrowheads indicate the ventral extreme of the ventral horn. $c$, Background labeling in transverse section processed simultaneously as in $b$ except incubation was in the presence of both $5 \mathrm{nM}\left[{ }^{3} \mathrm{H}\right] \mathrm{CHA}$ and $10 \mu \mathrm{M}$ unlabeled (-)PIA. 

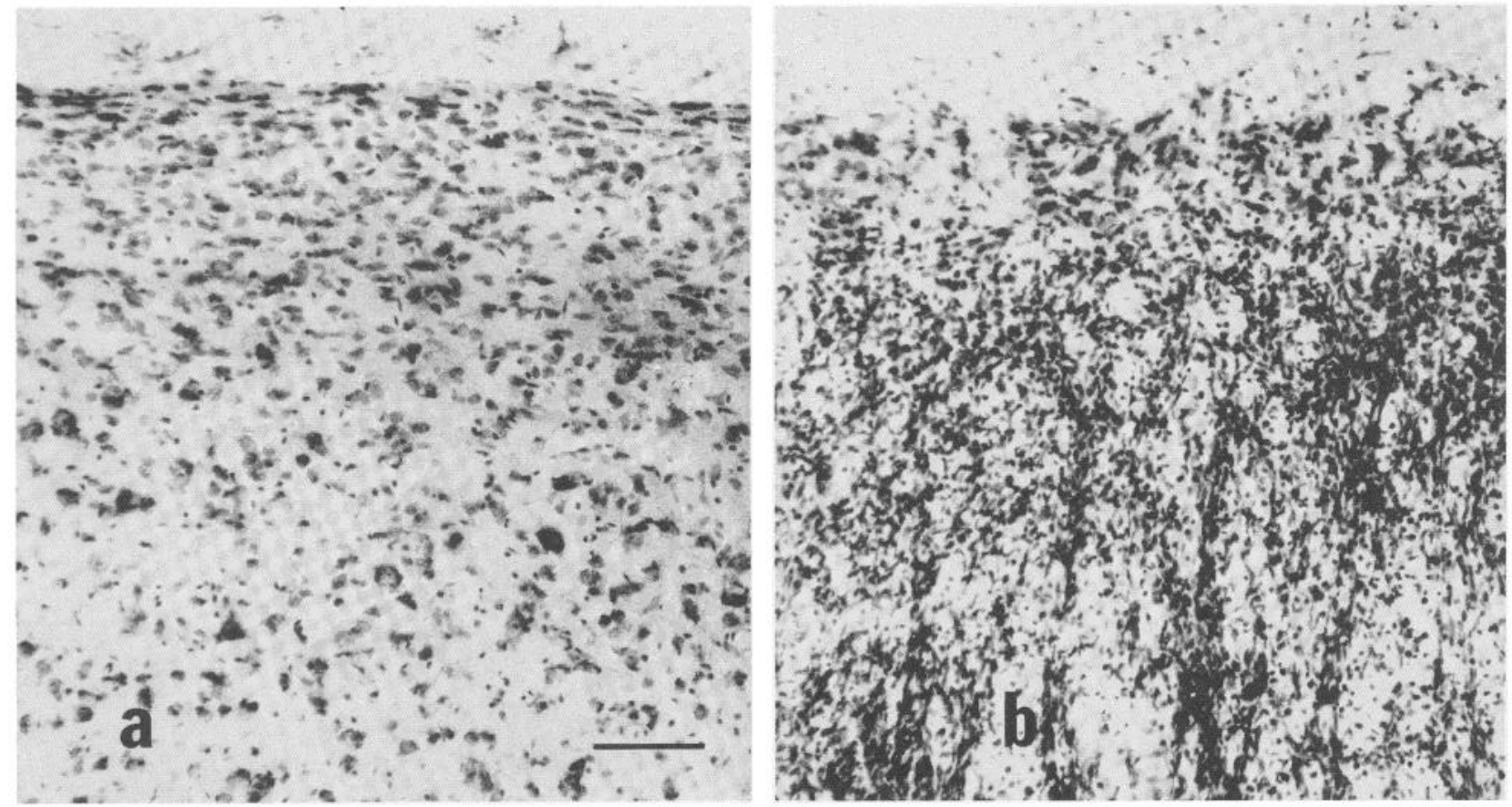

Figure 4. Photomicrographs of parasagittal sections of normal $(a)$ and KA-injected $(b)$ dorsal spinal cord stained with cresyl violet. Note the loss of neuronal cell bodies and intense gliosis in $b$. The section shows layers I through IV of the dorsal horn. Scale bar $=100 \mu \mathrm{m}$.

TABLE III

The levels of $\left[{ }^{3} \mathrm{H}\right] \mathrm{CHA}$-binding sites in rat spinal cord following injections of KA into the dorsal horn

Male Sprague-Dawley rats were either sham-operated, saline-injected, or KA-injected and were allowed to recover for 7 days. Values represent means \pm SEM from three separate experiments with the number of animals indicated in parentheses. Specific binding was determined as total binding ( 2 to $2.5 \mathrm{nM}\left[{ }^{3} \mathrm{H}\right] \mathrm{CHA}$ ) minus nonspecific binding using $10 \mu \mathrm{M}$ CHA. All samples were run in duplicate.

\begin{tabular}{cclc}
\hline \multirow{2}{*}{$\begin{array}{c}\text { Spinal } \\
\text { Region }\end{array}$} & Sham & \multicolumn{2}{c}{ Treatment } \\
\cline { 3 - 4 } & \multicolumn{3}{c}{ specific binding (fmol/mg of protein } \\
Dorsal & $75.8 \pm 4.2(4)$ & $\begin{array}{l}79.9 \pm 3.0 \\
\text { KA }\end{array}$ \\
Ventral & $61.6 \pm 2.3(4)$ & $\begin{array}{l}(4) \\
4.0 \pm 2.8 \pm 3.2(8)^{a} \\
(5)\end{array}$ \\
\end{tabular}

${ }^{a} p<0.01 \mathrm{KA}$ - versus saline-injected animals.

${ }^{b} \mathrm{NS}$, not significant.

\section{Discussion}

This report presents the first characterization and localization of adenosine receptors in subdivisions of the spinal cord. In membranes from whole spinal cord, Williams and Risley (1980), using $\left[{ }^{3} \mathrm{H}\right] 2 \mathrm{Cl}-\mathrm{Ad}$, and Patel et al. (1982), using $\left[{ }^{3} \mathrm{H}\right]$ $\mathrm{CHA}$ in single concentrations, reported $59 \%$ and $72 \%$ less binding, respectively, than, for example, in hippocampus. In a previous study on membranes from whole spinal cord, we found the density and affinity of $\left[{ }^{3} \mathrm{H}\right] \mathrm{CHA}$ binding comparable to those in most brain regions (Geiger et al., 1984). Qualitative autoradiographic studies demonstrated and the present results confirm that SG of the spinal cord contains levels of adenosine receptors as high as many brain regions (Goodman and Snyder, 1982). In addition, the present study demonstrates quantitatively that adenosine receptors in both the dorsal and, to a lesser extent, the ventral spinal cord are concentrated in the spinal cord grey matter. Saturation binding analysis indicated a single class of high affinity sites for $\left[{ }^{3} \mathrm{H}\right] \mathrm{CHA}$ in both regions, and the $K_{D}$ values in dorsal and ventral spinal cord were similar to those in brain. The $B_{\max }$ values for ventral horn tissue were consistently $31 \%$ less than for dorsal horn.

Previous receptor-binding studies in brain have shown that adenosine receptors are not only heterogeneously distributed but that the regional distribution of $A_{1}$ receptors differs from that of $A_{2}$ receptors. $A_{1}$ receptors have been identified in the cerebellum, hippocampus, striatum, cerebral cortex, and midbrain but not in hypothalamus, and $\mathrm{A}_{2}$ sites are located in striatum and hippocampus (Fredholm et al., 1982; Ebersolt et al., 1983). In view of these findings, the subtypes of adenosine receptors present in spinal cord need to be considered. According to current classification, $A_{1}$ receptors are characterized by nanomolar affinities and mediate inhibition of adenylate cyclase activity, whereas $\mathrm{A}_{2}$ sites are of lower affinity (micromolar) and mediate stimulation of adenylate cyclase (Van Calker et al., 1979; Londos et al., 1980). Londos et al. (1980) found that NECA was less potent than (-)-PIA for inhibiting adenylate cyclase at $A_{1}$ sites in adipocytes and brain tissue. Van Calker et al. (1979) also found (-)-PIA to inhibit adenylate cyclase selectively in glial primary cell cultures with an affinity up to 100 times greater than that of (+)-PIA. No such stereoselectivity was noted for $\mathrm{A}_{2}$ sites. In addition, $2 \mathrm{Cl}$-Ad is 10 times more potent than (-)-PIA at $\mathrm{A}_{2}$ sites (Smellie et al., 1979). The higher affinity of (-)-PIA (at least 10 -fold) than (+)-PIA in displacing radioligands from adenosine receptors and the relative pharmacological potencies of various analogues have been proposed as criteria for distinguishing $A_{1}$ or $A_{2}$ receptors (Daly et al., 1981). Methylxanthines do not differentiate between $A_{1}$ and $A_{2}$ sites. In the present study (-)-PIA was approximately 9 times more potent than (+)-PIA in displacing $\left[{ }^{3} \mathrm{H}\right] \mathrm{CHA}$ in dorsal and ventral spinal cord. Furthermore, NECA and 2Cl-Ad were less potent than (-)-PIA. These data from spinal cord show the pharmacological potencies of the analogues to be similar to those in brain. However, one consistent difference noted was the greater than 2-fold higher potency of NECA than 2Cl-Ad in displacing $\left[{ }^{3} \mathrm{H}\right] \mathrm{CHA}$ in ventral horn compared to dorsal horn and brain, where this ligand exhibited equal potencies. The potential physiological relevance 
of this disparity is unclear. The actions of adenosine analogues on adenylate cyclase constitute one criterion of receptor classification and, in the absence of these types of data for spinal cord, designation of these sites as $\mathrm{A}_{1}$ can only be tentative. Nevertheless, the results indicate the presence in spinal cord of the $A_{1}$ subtype.

The high levels of adenosine receptors in the SG of the spinal cord and the similar rank order of competing drugs for these receptors in brain and spinal cord tissue led us to examine the spinal neuronal systems containing these receptors. In the brain there is precedence for a presynaptic location of adenosine receptors on both long and short projection systems, such as those on retinal projections to the superior colliculus and parallel fibers of cerebellar granule cells (Goodman et al., 1983), respectively. Also, adenosine receptors are associated with local interneurons in the hippocampus and striatum (Murry and Cheney, 1982; Wojcik and Neff, 1983a). The present results indicate that in the spinal cord, adenosine $A_{1}$ receptors are not associated with terminals of descending long axonal projections in either the dorsal or ventral horn. Nor was evidence found for a presynaptic location of these receptors on terminals of primary afferents in the spinal cord, as ascertained in animals receiving either capsaicin treatment neonatally or dorsal rhizotomies. Both approaches were employed since in the former methods only unmyelinated primary afferents are preferentially depleted and compensatory changes during maturation of the animal may confound interpretations (Nagy and Hunt, 1983). Because of the limited quantities of postlesion tissue, we were unable to measure $K_{D}$ and $B_{\max }$ values via saturation-binding experiments. Therefore, lack of change in $\left[{ }^{3} \mathrm{H}\right] \mathrm{CHA}$ binding as measured using a single concentration of $\left[{ }^{3} \mathrm{H}\right] \mathrm{CHA}$ may have been due to changes in $K_{D}$ and $B_{\max }$ values which offset each other. However, it is unlikely that the $K_{D}$ values changed since no changes in $K_{D}$ or $B_{\max }$ were seen in capsaicin-treated animals nor in other reports in the literature where CNS lesions were performed. Also, the remote possibility that decreased numbers of adenosine receptors on presynaptic terminals were compensated by a supersensitivity of postsynaptic sites is discounted because the binding levels measured were identical to those measured in control animals. Still these possibilities cannot be excluded.

In contrast to the negative results from capsaicin-treated hemitransected, and dorsal rhizotomy animals, KA-induced lesions of the dorsal horn reduced $\mathrm{A}_{1}$ receptor levels by $33 \%$. We have not conducted extensive neurochemical analysis to determine whether KA lesions in the spinal cord induce specific destruction of intrinsic neurons at the injection site or whether terminals and axons originating from neurons outside this site are affected as well. However, in view of the absence of $A_{1}$ receptors on at least two major systems innervating the dorsal horn, together with neuronal loss and massive glial proliferation following $\mathrm{KA}$ injections into this area, the present results indicate that a substantial proportion of $\mathrm{A}_{1}$ sites are located on neurons in the dorsal horn. This is pertinent since these sites have been found on glial cells in tissue culture (Van Calker et al., 1979). Since $\left[{ }^{3} \mathrm{H}\right] \mathrm{CHA}$-binding sites have been shown autoradiographically to be particularly rich in the $S G$, their reduced levels following $\mathrm{KA}$ may have been due largely to the loss of $\mathrm{SG}$ interneurons bearing these sites. In this event greater reductions may have been presently observed after KA treatment had there been less sparing of SG neurons at distances in tissues slightly removed from the injection site but included in receptor measurements. Although we suggest a location of $A_{1}$ sites on neurons in the $S G$, it is presently not clear whether these sites occur on presynaptic terminals and short intersegmental axons of these neurons or their dendrites and perikarya.

The presence of $\left[{ }^{3} \mathrm{H}\right] \mathrm{CHA} \mathrm{A}_{1}$ receptors in the dorsal spinal cord and their enrichment in the SG (Goodman and Snyder,
1982) suggests their association with neurons which process sensory input and implicates adenosine as a modulator of sensory function. Previous studies have demonstrated the actions of adenosine analogues on locomotor activity and on the electrical activity of neurons in the brain (Dunwiddie and Hoffer, 1980; Snyder, 1981). Behavioral studies have also shown that adenosine agonists increase and the antagonists decrease nociceptive thresholds in animals (Crawley et al., 1981; Yarbrough and McGuffin-Clineschmidt, 1981; Holmgren et al., 1983). Thus, adenosine agonists and antagonists may act not only on brain but also on the spinal cord to influence nociception.

\section{References}

Cheng, Y. C., and H. R. Prusoff (1973) Relationship between the inhibition constant $\left(K_{i}\right)$ and the concentrations of inhibitor which causes $50 \%$ inhibition $\left(\mathrm{IC}_{50}\right)$ of an enzymatic reaction. Biochem. Pharmacol. 22: 3099-3108.

Crawley, J. N., J. Patel, and P. J. Marangos (1981) Behavioral characterization of two long-lasting adenosine analogs: Sedative properties and interaction with diazepam. Life Sci. 29: 2623-2630.

Daly, J. W., R. F. Bruno, and S. H. Snyder (1981) Adenosine receptors in the central nervous system: Relationship to the central actions of methylxanthines. Life Sci. 28: 2083-2097.

Dunwiddie, T. V., and B. J. Hoffer (1980) Adenine nucleotides and synaptic transmission in the in vitro rat hippocampus. Br. J. Pharmacol. 69: 59-68.

Ebersolt, C., J. Premont, A. Prochiantz, M. Perez, and J. Bochaert (1983) Inhibition of brain adenylate cyclase by $A_{1}$ adenosine receptors: Pharmacological characteristics and locations. Brain Res. 267: 123-129.

Fredholm, B. B., and P. Hedqvist (1980) Modulation of neurotrans mission by purine nucleotides and nucleotides. Biochem. Pharmacol. 29: $1635-1643$.

Fredholm, B. B., B. Jonzon, E. Lindgren, and K. Lindstrom (1982) Adenosine receptors mediating cyclic AMP production in the rat hippocampus. J. Neurochem. 39: 165-175.

Galindo, A., K. Krnjevic, and S. Schwartz (1967) Micro-iontophoretic studies on neurones in the cuneate nucleus. J. Physiol. (Lond.) 192: 359-377.

Geiger, J. D., F. S. LaBella, and J. I. Nagy (1984) Ontogenesis of adenosine receptors in the central nervous system of the rat. Dev. Brain Res., in press.

Goodman, R. R., and S. H. Snyder (1982) Autoradiographic localization of adenosine receptors in rat brain using $\left[{ }^{3} \mathrm{H}\right]$ cyclohexyladenosine. J. Neurosci. 2: 1230-1241.

Goodman, R. R., M. J. Kuhar, L. Hester, and S. H. Snyder (1983) Adenosine receptors: Autoradiographic evidence for their localization on axon terminals of excitatory neurons. Science 220: 967-969.

Holmgren, M., T. Hednar, G. Nordberg, and T. Mellstrand (1983) Antinociceptive effects in the rat of an adenosine analogue, $N^{6}$. phenylisopropyl adenosine. J. Pharm. Pharmacol. 35: 679-680.

Holton, F. A., and P. Holton (1954) The capillary dilator substances in dry powder of spinal roots; a possible role of adenosine triphosphate in chemical transmission from nerve endings. J. Physiol. (Lond.) 126: 124-140.

Holton, P. (1959) The liberation of adenosine triphosphate on antidromic stimulation of sensory nerves. J. Physiol. (Lond.) 145: 494504.

Jahr, C. E., and T. M. Jessell (1983) ATP excites a subpopulation of rat dorsal horn neurons. Nature 304: 730-733.

Krishtal, O. A., S. M. Marchenko, and V. I. Pidoplichko (1983) Receptor for ATP in the membrane of mammalian sensory neurones. Neurosci. Lett. 35: 41-45.

Lee, K. S., P. Schubert, M. Reddington, and G. W. Kreutzberg (1983) Adenosine receptor density and the depression of evoked neuronal activity in the rat hippocampus in vitro. Neurosci. Lett. 37: 81-85.

Londos, C., D. M. F. Cooper, and J. Wolff (1980) Subclasses of external adenosine receptors. Proc. Natl. Acad. Sci. U. S. A. 77: 2551-2554.

Lowry, O. H., N. J. Rosebrough, A. L. Farr, and R. J. Randall (1951) Protein measurement with the Folin phenol reagent. .J. Biol. Chem. 193: $265-275$.

Munson, P. J., and D. Rodbard (1980) LIGAND: A versatile comput- 
erized approach for characterization of ligand-binding systems. Anal. Biochem. 107: 220-239.

Murray, T. F., and D. L. Cheney (1982) Neuronal location of $N^{6}$ cyclohexyl ${ }^{3} \mathrm{H}$-adenosine binding sites in rat and guinea-pig brain. Neuropharmacology 21: 575-580.

Nagy, J. I., and S. P. Hunt (1982) Fluoride-resistant acid phosphatasecontaining neurons in dorsal root ganglia are separate from those containing substance $P$ or somatostatin. Neuroscience 7: 89-97.

Nagy, J. I., and S. P. Hunt (1983) The termination of primary afferents within the rat dorsal horn: Evidence for rearrangement following capsaicin treatment. J. Comp. Neurol. 218: 145-158.

Nagy, J. I., and D. Van Der Kooy (1983) Effects of neonatal capsaicin treatment on nociceptive thresholds in the rat. J. Neurosci. 3: 11451150 .

Nagy, J. I., L. L. Iversen, M. Goedert, D. Chapman, and S. P. Hunt (1983) Dose-dependent effects of capsaicin on primary sensory neurons in the neonatal rat. J. Neurosci. 3: 399-406.

Paalzow, G., and L. Paalzow (1973) 'The effect of caffeine and theophylline on nociceptive stimulation in the rat. Acta Pharmacol. Toxicol. 32: 22-32.

Patel, J., P. J. Marangos, J. Stivers, and F. K. Goodwin (1982) Characterization of adenosine receptors in brain using $N^{6}$-cyclohexyl $\left[{ }^{3} \mathrm{H}\right]$ adenosine. Brain Res. 237: 203-214.

Phillis, J. W., and P. H. Wu (1981) The role of adenosine and its nucleotides in central synaptic transmission. Prog. Neurobiol. 16: 187-239.

Salt, T. E., and R. G. Hill (1983) Excitation of single sensory neurones in the rat caudal trigeminal nucleus by iontophoretically applied adenosine 5'triphosphate. Neurosci. Lett. 35: 53-57.
Scadding, J. W. (1981) Development of ongoing activity, mechanosensitivity, and adrenaline sensitivity in severed peripheral nerve axons. Exp. Neurol. 73: 345-364.

Schubert, P., W. Komp, and G. W. Kreutzberg (1974) Correlation of $5^{\prime}$-nucleotidase activity and selective transneuronal transfer of adenosine in the hippocampus. Brain Res. 168: 419-424.

Scott, T. G. (1967) The distribution of 5 'nucleotidase in the brain of the mouse. J. Comp. Neurol. 129: 97-114.

Smellie, F. W., J. W. Daly, T. V. Dunwiddie, and B. J. Hoffer (1979) The dextro and levorotatory isomers of $N^{6}$-phenylisopropyladenosine: Stereospecific effects on cyclic AMP-formation and evoked synaptic responses in brain slices. Lifc Sci. 25: 17391748.

Snyder, S. H. (1981) Adenosine receptors and the actions of methylxanthines. Trends Neurosci. 4: 242-244.

Van Calker, D., M. Muller, and B. Hamprecht (1979) Adenusine regulates via two different types of receptors, the accumulation of cyclic AMP in cultured brain cells. J. Neurochem. 33: 999-1005.

Williams, M., and E. A. Risley (1980) Biochemical characterization of putative central purinergic receptors by using 2 -chloro $\left[{ }^{3} \mathrm{H}\right]$ adenosine, a stable analog of adenosine. Proc. Natl. Acad. Sci. U. S. A. 77 6892-6896.

Wojcik, W. J., and N. H. Neff (1983a) Location of adenosine release and adenosine $A_{2}$ receptors to rat striatal neurons. Life Sci. 33: 755763.

Wojcik, W. J., and N. H. Neff (1983b) Adenosine $A_{1}$ receptors are associated with ccrebcllar granule cells. J. Neurochem. 11: 759-763.

Yarbrough, C. G., and J. C. McGuffin-Clineschmidt (1981) In vivo behavioral assessment of central nervous system purinergic receptors. Eur. J. Pharmacol. 76: 137-144. 